\title{
PERBEDAAN MOTIVASI UNTUK MELAKUKAN SENAM NIFAS PADA IBU POSTPARTUM YANG DIBERIKAN PENDIDIKAN KESEHATAN DENGAN YANG TIDAK DIBERIKAN PENDIDIKAN KESEHATAN DI RUMAH SAKIT BINA KASIH MEDAN
}

\author{
Jujuren Br. Sitepu \\ Politeknik Kesehatan Kemenkes Medan Jurusan Keperwatan Gigi
}

\begin{abstract}
Abstrak
Angka Kematian Ibu (AKI) merupakan salah satu indikator keberhasilan suatu pelayanan kesehatan. SKRT memperkirakan $60 \%$ kematian ibu akibat kehamilan terjadi setelah persalinan, dan 50\% kematian masa nifas terjadi dalam 24 jam pertama. Untuk meminimalkan masalah atau komplikasi pasca persalinan seperti resiko perdarahan pasca postpartum salah satu aktivitas yang dianjurkan adalah senam nifas. Tujuan dalam penelitian ini untuk mengetahui perbedaan motivasi untuk melakukan senam nifas pada ibu postpartum yang diberikan pendidikan kesehatan dengan yang tidak diberikan pendidikankesehatan di RSU BINA KASIH. Desain penelitian yang digunakan pada penelitian ini adalah penelitian kuantitatif. Rancangan penelitian ini menggunakan pra- eksperimental yaitu dengan metode staticgroup comparison design, dan uji statistik yang digunakan yaitu uji mann whitney. Besar sampel yang digunakan untuk masing-masing kelompok yaitu 30 responden. Teknik sampling yang digunakan adalah sampling Insidental. Data diperoleh dengan menggunakan kuesioner yang langsung diberikan kepada responden. Hasil penelitian menunjukkan bahwa pada kelompok responden dengan perlakuan diperoleh hasil sebagian besar memiliki motivasi tinggi (85 \%) sedangkan pada kelompok kontrol didapatkan (75\%) memiliki motivasi sedang dan sisanya memiliki motivasi rendah. Dari hasil uji beda yang dilakukan, didapatkan bahwa ada perbedaan motivasi untuk melakukan senam nifas pada ibu post partum yang diberikan pendidikan kesehatan dengan yang tidak diberikan pendidikan kesehatan, dengan p value sebesar 0.000 .
\end{abstract}

Kata Kunci : Perbedaan Motivasi, Senam Nifas, Ibu Postpartum

\section{PENDAHULUAN}

Angka Kematian Ibu (AKI) merupakan salah satu indikator keberhasilan suatu pelayanan kesehatan, berdasarkan Survei Demografi dan Kesehatan Indonesia (SDKI) 2009/2010 yang menunjukkan bahwa setiap jam terdapat 2 orang ibu bersalin meninggal dunia karena berbagai sebab (Ridwanamirudin, 2007). SKRT memperkirakan 60\% kematian ibu akibat kehamilan terjadi setelah persalinan, dan 50\% kematian masa nifas terjadi dalam 24 jam pertama. Postpartum atau masa nifas merupakan masa setelah partus selesai dan berakhirnya setelah kira-kira 6 minggu. Delapan jam pasca persalinan, ibu harus tidur terlentang untuk mencegah perdarahan. Sesudah 8 jam, ibu boleh miring ke kiri atau ke kanan untuk mencegah trombosis (Mansjoer Arif, 2007).

Para ibu pasca melahirkan cenderung takut untuk melakukan banyak gerakan. Ibu biasanya khawatir gerakan-gerakan yang dilakukannya akan menimbulkan dampak

yang tidak diinginkan. Setidaknya ada tiga alasan mengapa orang tidak melakukan senam nifas setelah persalinan, pertama, karena memang tidak tahu bagaimana senam nifas. Kedua karena terlalu bahagia dan yang dipikirkan hanya si kecil. Ketiga, jangankan berpikir untuk senam, untuk bangun saja terasa sakit. Senam nifas sebaiknya dilakukan dalam waktu 24 jam setelah melahirkan, secara teratur setiap hari.

Setelah 6 jam persalinan normal atau 8 jam setelah operasi sesar, ibu sudah boleh melakukan mobilisasi dini, termasuk senam nifas (Mutia Alisjahbana, 2008) . Saat melaksanakan senam nifas terjadi kontraksi otot-otot perut yang akan membantu proses involusi yang mulai setelah plasenta keluar segera setelah melahirkan. Ambulasi secepat mungkin dari frekuensi sangat diperlukan dalam proses involusi (tesisjogya,2006).

Peran bidan sebagai tenaga kesehatan menempati posisi utama dalam asuhan ibu-ibu post partum. Peran bidan yang dapat dilakukan salah satunya adalah peran bidan sebagai edukator yaitu peran dalam meningkatkan tingkat pengetahuanvtentang kesehatan, , sehingga terjadi perubahan perilaku dari klien setelah dilakukan promosi kesehatan.

\section{Tujuan Penelitian}

Tujuan Umum

Mengetahui tentang perbedaan motivasi untuk melakukan senam nifas pada ibu postpartum yang diberikan pendidikan kesehatan dengan yang tidak diberikan promosi kesehatan. 
Tujuan Khusus

a. Mengidentifikasi tentang motivasi untuk melakukan senam nifas pada ibu postpartum yang dilakukan pendidikan kesehatan

b. Mengidentifikasi tentang motivasi untuk melakukan senam nifas pada ibu postpartum yang tidak dilakukan pendidikan kesehatan.

c. Mengidentifikasi perbedaan motivasi untuk melakukan senam nifas pada ibu postpartum yang diberikan pendidikan kesehatan dengan ibu postpartum yang tidak diberikan pendidikan kesehatan.

\section{Manfaat Penelitian}

1. Bagi ibu postpartum

Mengetahui tentang pentingnya senam nifas dalam mencegah terjadinya kemungkinan komplikasi pasca persalinan dan proses pengembalian organorgan kandungan ke keadaan sebelum hamil.

\section{Bagi RS}

Dengan adanya penelitian ini diharapkan bidan dapat meningkatkanpelayanan asuhan kebidanan serta memberikan motivasi khususnya pada pelaksanaan senam nifas bagi ibu postpartum.

\section{Metode Penelitian}

A. Jenis dan Rancangan Penelitian

Metode penelitian yang digunakan dalam penelitian ini adalah metode kuantitatif sedangkan rancangan penelitian yang digunakan dalam penelitian ini adalah jenis rancangan penelitian pra- eksperimental yaitu dengan metode static-group comparison design (Nursalam, 2008).

\section{B. Populasi dan Sampel Penelitian}

Populasi dalam penelitian ini adalah semua ibu postpartum yang berada di ruang Melati RSU Bina Kasih Medan sebanyak 60 orang. Jumlah sampel dalam penelitian ini 60 orang, yang akan dibagi menjadi dua kelompok yaitu satu kelompok dengan perlakuan dan satu kelompok kontrol, dimana masing-masing kelompok dengan jumlah sampel 30 orang, dengan menggunakan tehnik sampling Insidental. Penelitian ini menggunakan dua instrument penelitian yaitu media untuk melakukan pendidikan kesehatan dan alat ukur berupa kuesioner yang digunakan untuk mengukur motivasi ibu postpartum. Dalam penelitian ini uji statistik yang digunakan adalah uji mann whitney (Sugiyono, 2009).

\section{Hasil Penelitian}

\section{A. Karakteristik Responden}

Tabel 4.1

Distribusi Frekuensi Karakteristik Responden Berdasarkan Umur, Tingkat Pendidikan dan Jenis Pekerjaan Ibu Postpartum Di RSU.BINA KASIH MEDAN

\begin{tabular}{l|c|c}
\hline \multicolumn{1}{c}{ Umur } & Perlakuan F (\%) & Kontrol F (\%) \\
\cline { 2 - 3 } \multicolumn{1}{c}{$<$ 25 tahun } & 20 & 20 \\
25-30 tahun & 50 & 45 \\
$>$ 30 tahun & 30 & 35 \\
\hline SD- SLTP & 30 & 33,33 \\
SLTA & 33,33 & 36,77 \\
D3 - S1 & 36,77 & 30 \\
\hline Petani & 20 & 25 \\
Buruh tani & 0 & 0 \\
Pedagang & 5 & 20 \\
Wirasawsta & 30 & 25 \\
Guru & 5 & 0 \\
PNS & 25 & 10 \\
IRT & 20 & 20 \\
\hline
\end{tabular}

4. Distribusi Frekuensi berdasarkan frekuensi Persalinan

Tabel 4.2

Distribusi Frekuensi Responden Berdasarkan Frekuensi Persalinan Pada Ibu postpartum di RSU.BINA KASIH MEDAN

\begin{tabular}{|c|c|c|}
\hline \multicolumn{3}{|c|}{ Kelompok } \\
\hline $\begin{array}{l}\text { Frekuensi } \\
\text { persalinan }\end{array}$ & Perlakuan F (\%) & Kontrol F (\%) \\
\hline 1 & 25 & 25 \\
\hline 2 & 40 & 40 \\
\hline 3 & 15 & 25 \\
\hline$>3$ & 20 & 10 \\
\hline Total & 100 & 100 \\
\hline
\end{tabular}




\section{B. Distribusi Frekuensi Berdasarkan Motivasi Ibu Postpartum Untuk Melakukan Senam Nifas}

Tabel 4. 3

Distribusi frekuensi responden berdasarkan motivasi untuk melakukan senam nifas pada ibu postpartum di RSU.BINA KASIH MEDAN

\begin{tabular}{c|c|c}
\hline \multirow{2}{*}{ Motivasi } & Perlakuan F (\%) & Kontrol F (\%) \\
\cline { 2 - 3 } Rendah & 0 & 20 \\
Sedang & 15 & 75 \\
Tinggi & 85 & 5 \\
\hline Total & 100 & 100 \\
\hline
\end{tabular}

\section{Perbedaan motivasi untuk melakukan senam nifas pada ibu postpartum yang dilakukan pendidikan kesehatan dengan yang tidak dilakukan pendidikan kesehatan}

Tabel 4.7

Perbedaan motivasi untuk melakukan senam nifas pada ibu postpartum yang dilakukan pendidikan kesehatan dengan yang tidak dilakukan pendidikan kesehatan di RSU BINA KASIH MEDAN

\begin{tabular}{|c|l|c|c|c|c|c|}
\hline no & \multicolumn{2}{|c|}{ Kelompok } & \multicolumn{3}{c|}{ Motivasi } & \multicolumn{2}{c|}{$\begin{array}{l}\text { p value } \\
\text { Mann Whitney }\end{array}$} \\
\hline 1 & $\begin{array}{l}\text { Perlakuan (dilakukan } \\
\text { pendidikankesehatan) }\end{array}$ & rendah & sedang & tinggi & & 0.000 \\
2 & $\begin{array}{l}\text { Kontrol (tidak dilakukan } \\
\text { Pendidikan kesehatan) }\end{array}$ & $4(20 \%)$ & $15(15 \%)$ & $17(85 \%)$ & $20(100 \%)$ & $20(100 \%)$ \\
\hline
\end{tabular}

Berdasarkan tabel 4.7 terlihat bahwa responden dengan perlakuan yang memiliki motivasi tinggi sebanyak 17 orang (85\%), dan motivasi sedang sebanyak 3 orang (15 \%) dengan sedangkan pada kelompok kontrol sebanyak 15 responden (75\%) memililki motivasi sedang, 4 orang (20\%) dengan motivasi rendah dan 1 orang (5\%) dengan motivasi tinggi. Pada penelitian ini juga didapatkan bahwa pvalue Mann-Withney sebesar 0.000, dimana alpha yang digunakan adalah 5\%,sehingga p value $(0.000)<$ alpha (0.05), berarti Ho ditolak. Kesimpulannya bahwa terdapat perbedaan yang bermakna antara kelompok yang diberikan pendidikankesehatan dengan kelompok yang tidak diberikan pendidikan kesehatan.

\section{Pembahasan}

\section{A. Karakteristik Responden}

Usia merupakan salah satu faktor yang mempengaruhi tingkat motivasi seseorang karena usia dapat menjadi tolak ukur kesiapan fisik dan mental seseorang dalam menghadapi masalah. Semakin cukup umur tingkat kematangan dan kekuatan seseorang akan lebih matang dalam berpikir. Semakin tua umur seseorang semakin konstruktif dalam menggunakan koping terhadap masalah yang dihadapi (wikipedia.com).

Hasil penelitian menunjukkan bahwa untuk kelompok perlakuan berdasarkan umur, paling banyak berusia antara 25-30 tahun sebanyak 10 orang (50\%), diikuti oleh umur diatas 30 tahun sebanyak 6 orang (30\%) dan umur kurang dari 25 tahun sebanyak 4 orang (20\%). Pada kelompok kontrol juga didominasi oleh usia 25-30 tahun yaitu sebanyak 9 orang (45 \%). Usia 25-30 tahun merupakan usia subur, dimana pada usia ini merupakan usia yang matang untuk ibu-ibu merencanakan suatu kehamilan, baik itu pada kehamilan yang pertama, kedua ataupun ketiga karena pada usia itu organ-organ reproduksi telah siap untuk dibuahi. Jika dilihat berdasarkan tingkat pendidikan, sebagian besar dari responden baik responden dengan perlakuan pendidikan kesehatan yang sejumlah 8 orang (40\%) dan kelompok kontrol sejumlah 7 orang (35\%) adalah berpendidikan SLTA. Hal ini sudah sesuai dengan faktor-faktor yang mempengaruhi motivasi yang menyebutkan bahwa faktor-faktor yang mempengaruhi motivasi seseorang untuk melakukan sesuatu diantaranya ada tingkat pendidikan dan pekerjaan, dimana tingkat pendidikan dan jenis pekerjaan yang lebih baik dapat mendorong seseorang untuk mendapatkan atau bersedia untuk melakukan sesuatu demi mencapai tujuan yang diharapkan.

Pendidikan berarti bimbingan yang diberikan oleh seseorang terhadap perkembangan orang lian menuju ke arah suatu cita-cita tertentu. Pada umumnya semakin tinggi pendidikan maka semakin baik pula tingkat pengetahuannya sebaliknya pendidikan yang kurang akan menghambat perkembangan sikap seseorang terhadap nilai-nilai yang baru diperkenalkan. Pengetahuan itu sendiri merupakan kemampuan seseorang untuk mengingat fakta, simbol, prosedur tehnik dan teori. Semakin tinggi pendidikan seseorang dapat mempengaruhi tingginya motivasi seseorang. Pendidikan dapat mempengaruhi seseorang termasuk juga perilaku seseorang akan pola hidup terutama dalam memotivasi untuk sikap peran serta dalam perkembangan kesehatan. Sedangkan pekerjaan adalah kesibukan yang harus dilakukan terutama untuk menunjang kehidupannya dan kehidupan keluarganya.

Pekerjaan bukanlah sumber kesenangan, tetapi lebih banyak merupakan cara mencari nafkah yang membosankan, berulang dan banyak tantangan. Bekerja umumnya merupakan kegiatan yang menyita waktu 
,bekerja merupakan kegiatan yang menimbulkan motivasi (wikipedia.com). Selain itu tingkat pendidikan erat kaitannya dengan tingkat pengetahuan, dimana tingkat pengetahuan sangat mempengaruhi seseorang dalam melakukan suatu tindakan, salah satunya adalah melakukan senam nifas. Semakin banyak pengetahuan seseorang maka semakin baik pula tingkat motivasinya terhadap tindakan atau perilaku yang lebih baik. Pengetahuan seseorang yang kurang menyebabkan seseorang tidak mengetahui pentingnya manfaat senam nifas bagi ibu postpartum.

Berdasarkan hasil penelitian setelah diberikan pendidikan kesehatan didapatkan bahwa ibu-ibu yang melahirkan untuk pertama kalinya memiliki motivasi untuk melakukan senam nifas lebih baik daripada ibu-ibu yang sudah lebih dari sekali melahirkan. Sedangkan untuk hari persalinan, ibu postpartum yang sudah hari ke- 3 atau lebih dari 3 hari melahirkan memiliki motivasi yang sama baiknya dengan yang sebelum 2 hari pasca persalinan. Hal ini tidak sesuai dengan faktor-faktor yang menyebabkan seseorang malas untuk melakukan senam nifas yang menyebutkan bahwa ibu-ibu postpartum cenderung malas untuk melakukan senam nifas karena dipengaruhi oleh :

1. Faktor Fisiologis

Faktor fisiologis juga mempengaruhi seseorang dalam melakukan senam nifas, misalnya karena rasa nyeri pasca melahirkan menyebabkan seseorang malas dan takut untuk melakukan senam nifas, karena dikwatirkan gerakan-gerakan dalam senam menimbulkan dampak yang kurang baik.

\section{Faktor Psikologis}

Psikologis sangat berperan penting dalam kesiapan seseorang untuk melakukan senam nifas. Rasa bahagia terhadap penerimaan bayi dan kesibukan dalam mengurus bayi membuat seorang ibu lupa untuk melakukan senam nifas yang mana sangat penting dalam pengembalian organ-organ reproduksi pasca melahirkan. (Mutia, 2008).

\section{B. Perbedaan motivasi untuk melakukan senam nifas}

Hasil penelitian yang dilakukan oleh peneliti menunjukkan bahwa diperoleh hasil untuk kelompok perlakuan atau yang diberikan pendidikan kesehatan terdapat 17 orang (85 \%) memiliki motivasi untuk melakukan senam nifas tinggi dan 3 orang (15\%) memiliki motivasi yang sedang. Sedangkan untuk kelompok kontrol diperoleh hasil bahwa responden yang tidak diberikan pendidikan kesehatan memiliki motivasi rendah untuk melakukan senam nifas yaitu sebanyak 4 orang (20\%) dan motivasi sedang sebanyak 15 orang (75\%). Pada penelitian ini menggunakan uji statistik yaitu uji Mann withney dengan p value 0.000 dan alpha $5 \%$, dimana jika p value lebih kecil dari alpha maka Ho ditolak, yang artinya terdapat perbedaan motivasi yang signifikan antara responden yang diberikan pendidikan kesehatan dengan responden yang tidak diberikan pendidikan kesehatan.

Sesuai dengan hasil penelitian, pendidikan kesehatan ternyata berperan dalam perubahan sikap individu, karena didalam pendidikan kesehatan terkandung unsur- unsur komunikasi dan khususnya dalam upaya mengubah sikap individu, strategi yang dapat digunakan adalah strategi persuasif. Selain itu pendidikan kesehatan juga memiliki tujuan untuk merubah perilaku orang atau masyarakat dari perilaku tidak sehat menjadi perilaku sehat. Dalam pendidikan kesehatan terdapat berbagai tahapan-tahapan, salah satunyaadalah tahap motivasi. Pada tahap ini perorangan atau masyarakat diharapkan setelah mengikuti pendidikan kesehatan, benar-benar merubah perilaku sehari-harinya, sesuai dengan perilaku yang dianjurkan oleh pendidikan kesehatan. Kegiatan-kegiatan ini dilakukan secara berurutan, tahap demi tahap, karena itu pelaksana harus menguasai benar ilmu komunikasi untuk tahap sensitisasi dan publisitas serta edukasi atau ilmu belajar mengajar yang sungguh - sungguh untuk melaksanakan pendidikan kesehatan pada tahap edukasi dan motivasi (Nursalam,2008).

Pendidikan kesehatan merupakan upaya menerjemahkan apa yang telah diketahui tentang kesehatan ke dalam perilaku yang diinginkan dari perorangan ataupun masyarakat melalui proses pendidikan. Dengan dilakukan pendidikan kesehatan maka pengetahuan seseorang atau responden tentang senam nifas akan terjadi peningkatan sehingga antara hasil penelitian terhadap responden yang diberikan pendidikan kesehatan dengan yang tidak diberikan pendidikan kesehatan akan berbeda hasilnya.Berdasarkan penelitian yang telah dilakukan oleh peneliti didapatkan hasil bahwa motivasi mereka memang berbeda.

\section{Kesimpulan Dan Saran}

\section{A. Kesimpulan}

1. Pada kelompok responden dengan perlakuan diperoleh hasil bahwa sebagian besar memiliki motivasi tinggi yaitu sebanyak 17 orang dan 3 orang memiliki motivasi sedang.

2. Pada kelompok kontrol didapatkan bahwa 15 orang memiliki motivasi sedang dan sisanya memiliki motivasi rendah sebanyak 4 orang dan tinggi sebanyak 1 orang.

3. Terdapat perbedaan yang signifikan antara kelompok yang diberikan pendidikan kesehatan dengan kelompok kontrol.

\section{B. Saran}

\section{Bagi ibu postpartum}

Setelah dilakukan penelitian ini diharapkan ibu postpartum bertambah tingkat pengetahuannya, khususnya tentang senam nifas dan dari hasil penelitian yang menunjukkan bahwa motivasi ibu postpartum tergolong baik maka diharapkan sesegera mungkin mereka untuk dapat melaksanakan senam nifas.

\section{Bagi RS}

Setelah dilakukan penelitian tentang pendidikan kesehatan terhadap motivasi untuk melakukan senam nifas pada ibu postpartum, diharapkan dari pihak RS berkenan untuk memberikan fasilitas untuk ibu-ibu postpartum kaitannya dengan pelaksanaan senam nifas, yaitu dengan membuka klinik untuk senam hamil dan 
senam nifas di rehabilitasi medik. Berdasarkan penelitian tersebut juga RS dapat memprogramkan pendidikan kesehatan tentang senam nifas kepada para ibu-ibu

postpartum di RSUBina Kasih Medan

3. Bagi institusi pendidikan Untuk institusi pendidikan, setelah dilakukan penelitian ini diharapkan penelitian ini dapat membantu dalam pengembangan ilmu keperawatan maternitas.

4. Bagi peneliti selanjunya

Untuk penelitian selanjutnya perlu diadakan penelitian yang lebih mendalam kaitannya dengan pelaksanaan senam nifas. Penelitian ini masih jauh dari sempurna maka diharapkan peneliti selanjutnya dapat lebih menyempurnakannya dengan menambahkan jumlah responden dan dengan menggunakan metode penelitian dan analisa yang berbeda.

\section{DAFTAR PUSTAKA}

Alimul H, Azis. Riset Keperawatan dan Tehnik Penulisan Ilmiah. Jakarta : Salemba Medika. 2003.

--. Pengantar Konsep Dasar Keperawatan. Jakarta : Salemba Medika.2004.

Bobak, Lowdermilk, Jensen. Buku Ajar Keperawatan Maternitas. Jakarta : EGC. 2004.

Candra, B. Pengantar Statistik kesehatan. Jakarta : EGC. 1995
Helen, Farrer. Perawatan Maternitas.Edisi 2. Jakarta : EGC. 1999.

Hanifa, Wiknjosastro. Ilmu Kebidanan. Edisi 3. Jakarta : Yayasan Bina Pustaka Sarwono Prawiroharjo. 2002.

Mansjoer,arif. Kapita Selekta Kedokteran. Edisi 3. Jakarta : Media Aesculapius. 1999.

Nursalam, M.nur .Manajemen Keperawatan : Aplikasi dalam Praktik Keperawatan Profesional. Edisi 2. Jakarta: Salemba Medika. 2007.

Purwanto, dkk. Metode Penelitian Kuantitatif Untuk Administrasi Publik Dan Masalah Masalah Sosial.Yogyakarta : Gava Madia. 2007.

Safaria, Triantoro. Kepemipinan.Edisi pertama.Yogyakarta: Graha Ilmu. 2004

Suarsi, Yayan Bahtiar.Manajemen Keperawatan dengan Pendektan Praktis. Jakarta Erlangga 2004.

Suherni. Perawatan masa nifas. Yogyakarta : Fitramaya. 2008.

Sugiyono. Statistik untuk Penelitian. Bandung : Alfabeta. 2009

Senam nifas. 2006. 19 oktober, http://rsiaasamarinda.netre.net.

Pengaruh frekuensi senam nifas terhadap perubahan fundus uteri. 2006, http://tesisjogya.com.

Alisjahbana, Mutia.Senam Nifas, Senam setelah melahirkan. 2008. 12 Oktober, 